\title{
ANALISIS METODE ECONOMIC ORDER QUANTITY (EOQ) SEBAGAI DASAR PENGENDALIAN PERSEDIAAN BAHAN BAKU (STUDI PADA YANKEES BAKERY, KECAMATAN KERTOSONO)
}

\author{
Selvi Santosa; Gandung Satriyono; Rinto Nurbambang \\ Fakultas Ekonomi Universitas Kadiri \\ *e-mail : gandungsatriyono@unik-kediri.ac.id
}

\begin{abstract}
The current study aims to analyze the supply of raw materials for yankees bakery bread specifically for wheat flour, granulated sugar. This research is done for 2 months, from January to February 2018. Data analysis is used by researchers using the EOQ (Economic Order Quantity) to carry out orders to determine how many orders. From the results of this study the amount of inventory is optimal, EOQ of wheat flour in the third quarter of 2017 is $4,807.29 \mathrm{~kg}$, dosage is $137.28 \mathrm{~kg}$, done (ROP), the remaining stock is $265.68 \mathrm{~kg}$, the total cost is Rp. 971,420. The fourth quarter of 2017 is 5,217.66 kg frequency 2 times, safety supplies $69 \mathrm{~kg}$, reorder (ROP) stocks in warehouses remaining $198.11 \mathrm{~kg}$, the total cost of inventory is Rp. 1,054,346. Based on the results of the study concluded that EOQ is more efficient. Then the cost of the raw material for Yankees Bakery is used EOQ in the supply of raw materials.
\end{abstract}

Keywords: Preparation Analysis, bread raw material, Yankees Bakery

\begin{abstract}
Abstrak
Penelitian saat ini bertujuan menganalisis sediaan bahan baku roti yankees bakery khusus bahan tepung terigu, gula pasir. Penelitian yang ini dikerjakan lamanya 2 bulan, dari bulan Januari hingga bulan Februari 2018. Analisis data dipergunakan peneliti menggunakan EOQ (Economic Order Quantity) melaksanakan pesanan menentukan seberapa banyak pesanan. Dari hasil penelitian ini jumlah persediaan menjadi optimal, EOQ tepung terigu triwulan tiga tahun 2017 banyaknya $4.807,29 \mathrm{~kg}$, sediaan 137,28 kg, dilakukan (ROP) sediaan sisa 265,68 kg, total biaya Rp. 971.420. Triwulan keempat tahun 2017 sebanyak 5.217,66 kg frekuensi $2 \mathrm{kali}$, persediaan pengaman $69 \mathrm{~kg}$, melakukan pemesanan ulang (ROP) sediaan di gudang tersisa $198,11 \mathrm{~kg}$, total biaya persediaan sebesar Rp. 1.054.346. Berdasarkan hasil penelitian disimpulkan EOQ lebih efisien. Maka hematan biaya sedia bahan baku Yankees Bakery gunakan EOQ di sediaan bahan baku.
\end{abstract}

Kata kunci : Analisis Sediaan, bahan baku roti, Yankees Bakery 


\section{PENDAHULUAN}

Sejalan kemodernan teknologi serta pengintensifan kegiatan individu dalam kawasan perusahaan membawa dampak kompetisi yang selektif dalam lingkungan bisnis. Memerlukan perhatian khusus dalam hal perencanaan dan manajemen.kualitas pelayanan dan kualitas produk sangat bermanfaat (Afif, 2015) Jaranan merupakan kesenian tradisional yang diturunkan dari zaman nenek moyang dulu sampai saat ini masih di senanggi masyarakat baik dari anak kecil maupun orang dewasa(Dewandaru bothy, 2016)Jika pasokan bahan baku terlalu besar, biaya penyimpanan akan lebih besar daripada bahan mentah. Kebalikannya, apabila inventori bahan baku yang terlampau minim hendak merajai penghasilan di mana industri akan kesukaran inventori bahan baku.

Persoalan mendasar yang ditemukan tatkala perencanaan dan pengelolaan bahan baku yakni guna memutuskan ketika bahan dipesan, jumlah bahan yang selalu di stok (safety stock) untuk menghindari kemacetan produksi. Selain menetapkan EOQ, perusahaanpun wajib menetapkan periode sistematisasi bahan dan baku akan dipakai Reorder Point (ROP) guna memesan bahan yang ditentukan di dalam EOQ yang tiada menghalangi fluensi aktivitas produksi.

Yankees Bakery adalah industri rumahan yang didedikasikan untuk produksi roti dan yang lebih spesifik dalam perencanaan. Pemesanan tepung terigu dan gula pasir semata mata didasarkan atas situasi faktual inventori di bangsal, jadi gelombang pembelian bahan baku, durasi pembelian serta kuanntitas bahan dan baku dibeli di masing - masing pembelian tidak tentukan secara memadai.

Bersumber pada latar belakang diatas, kemudian penyusun tertarik melangsungkan pengkajian digunakan judul "Analisis Metode Economic and Order Quantity (EOQ)

\section{Rumusan Masalah}

Berdasar latar belakang yang belum, rumusan masalah akan bahas penelitian ini adalah:

1. Berapa besar persediaan bahan dan baku (tepung terigu dan gula pasir) dioptimal menggunakan Economic and Order Quantity (EOQ) Yankees Bakery?

2. Berapa besar Reorder point sedia bahan baku gunakan Economic Order Quantity (EOQ) Yankees Bakery? 
3. Berapa besar total biaya gunakan Economic Order Quantity (EOQ) Yankees Bakery?

4. gimana jumlah biaya persediaan bahan dan baku digunakan metode kebijakan perusahaan dibanding menggunakan Economic and Order Quantity (EOQ) Yankees Bakery?

\section{Manfaat Penelitian}

Penelitian saat ini berharap memberi manfaat teoritis dan manfaat praktis.

\section{Manfaat Teoritis :}

1) Mengembangkan dari ilmu pengetahuan dan menetapkan, menerapkan teori yang diperoleh di perkuliahan dalam dunia usaha yang realistis.

2) Secara teori menerapkan pengendalian sediaan bahan dan baku Economic and Order Quantity (EOQ) pakai alat untuk menekan pada biaya produksi Yankees Bakery.

\section{Manfaat Praktis}

Manfaat praktis peneliti berguna berbagai pihak antaranya:

a. Bagi penulis, diharap dapat:

i. Menuhi satu syarat menyelesaikan studi Universitas Kadiri Fakultas Ekonomi Program Studi Manajemen.

ii. Meningkat pengetahuan mengenai sistem sediaan.

b. Bagi Universitas

Untuk menambah perbendaharaan perpustakaan bagi Universitas Kadiri pada umumnya dan fakultas Ekonomi jurusan Manajemen.

c. Bagi perusahaan

Berharap ada penelitian ini bisa dipergunakan evaluasi kebijakan yang diterapkan, pengelolaan sediaan bahan baku jadi optimal dan bisa meminimalkan anggaran persediaan.

d. Bagi Pembaca

Penelitian saat ini dipergunakan bahan kajian yang menjadi referensi penelitian perhitungan sediaan bahan baku mendatang. 


\section{TINJAUAN PUSTAKA}

\section{Penelitian Terdahulu}

Penelitian ini berkaitan dengan pengendalian sediaan bahan baku menggunakan Economic Order Quantity (EOQ) dilaksanakan dengan berapa peneliti yaitu:

\section{Tabel 1. Penelitian Terdahulu}

\begin{tabular}{|c|c|c|c|c|}
\hline No & $\begin{array}{c}\text { Nama } \\
\text { Peneliti }\end{array}$ & Judul & $\begin{array}{l}\text { Variabel dan } \\
\text { Alat Analisis }\end{array}$ & Hasil Penelitian \\
\hline 1 & $\begin{array}{l}\text { Ningrum } \\
\text { Atika Sari } \\
(2016)\end{array}$ & $\begin{array}{l}\text { Analisis } \\
\text { Pengendalian } \\
\text { Persediaan } \\
\text { Bahan Baku } \\
\text { Dengan } \\
\text { Metode EOQ } \\
\text { Pada } \\
\text { Perusahaan } \\
\text { Kecap Cap } \\
\text { Mencco } \\
\text { Kediri }\end{array}$ & $\begin{array}{l}\text { Jenis Penelitian: } \\
\text { Deskriptif } \\
\text { Kuantitatif } \\
\text { Variabel : } \\
\text { 1. Metode EOQ } \\
\quad \text { (independent) } \\
\text { 2. Persediaan } \\
\text { Bahan Baku } \\
\text { (dependent) } \\
\text { Analisis Data : } \\
\text { Metode EOQ }\end{array}$ & $\begin{array}{l}\text { Hasil dari bandingan total } \\
\text { pembiayaan gunakan EOQ } \\
\text { didapat sediaan sebesar } \\
5.996,3 \mathrm{~kg} \text { dengan pembiayaan } \\
\text { sediaan jumlah sebesar Rp. } \\
1.079 .217 .320 \text { dan nurut } \\
\text { kebijakan diperusahaan sebesar } \\
\text { Rp. } 1.326 .399 .829 \text {. jumlah biaya } \\
\text { sediaan baku kedelai diproses } \\
\text { produksi dikeluarkan perusahaan } \\
\text { Murni Jaya Kediri tahun } 2015 \text {, } \\
\text { EOQ lebih kecil dibanding } \\
\text { kebijakan perusahaan. Sehingga } \\
\text { EOQ efisien dan menghemat } \\
\text { biaya diterapkan pada } \\
\text { perusahaan. }\end{array}$ \\
\hline 2. & $\begin{array}{l}\text { Sutarti, } \\
\text { Sutriyono } \\
\text { dan Dhayal } \\
\text { Gustopo } \\
\text { (2016) }\end{array}$ & $\begin{array}{l}\text { Analisis } \\
\text { Pengendalian } \\
\text { Persediaan } \\
\text { Bahan Baku } \\
\text { Menggunakan } \\
\text { Metode } \\
\text { Economic } \\
\text { Order } \\
\text { Quantity } \\
\text { Dalam Upaya }\end{array}$ & $\begin{array}{l}\text { Jenis Penelitian : } \\
\text { Kuantitatif } \\
\text { Variabel : } \\
\text { 1.Metode EOQ } \\
\quad \text { (independent) } \\
\text { 2.Persediaan } \\
\text { Bahan Baku } \\
\text { (dependent) }\end{array}$ & $\begin{array}{l}\text { Hasil hitungan biaya sediaan cara } \\
\text { diterapkan perusahaan yaitu } \\
\text { sebesar Rp } 62.490 .462 \text {, dan hasil } \\
\text { biaya sediaan nurut } E O Q \text { tahun } \\
2016 \text { sebesar Rp } 61.440 .125 \text {. }\end{array}$ \\
\hline
\end{tabular}

\section{Landasan Teori}

\section{Persediaan}

Persediaan dalam perusahaan sangatlah penting guna kelancaran produksi. Menurut Haming dan Nurnajamuddin (2007:4) persediaan (inventory) diartikan bagai sumber daya dan ekonomi fisik perlu mengadakan dipelihara nunjang kelancaran proses produksi, 
meliputi yaitu bahan dan baku (raw material), produk jadi (finish product), komponen rakitan (component), bahan pembantu (substance material), dan barang sedang dalam proses pengerjaan (working in process inventory)

\section{Pengertian Bahan Baku}

Seluruh perusahaan yang berproduksi untuk menghasilkan satu atau beberapa macam produk tentu akan selalu memerlukan bahan baku untuk pelaksanaan proses produksinya. Bahan baku merupakan input yang penting dalam berbagai produksi. Pengertian bahan baku menurut Suadi (2000:64) adalah bahan yang menjadi bagian produk jadi dan dapat diidentifikasikan ke produk jadi.

Bahan baku nurut Syamsuddin (2001:281) yaitu sediaan dibeli perusahaan agar bisa diproses menjadi barang tengah jadi,dan akhir barang menjadi produk akhir perusahaan. Definisi atas, bisa disimpulkan bahan baku yaitu bahan digunakan produk di perusahaan.

\section{Economic and Order Quantity (EOQ)}

Salah satu sebagian model mengatur persediaan yaitu Economic and Order Quantity (EOQ). Heizer dan Render (2010:92) mengatakan EOQ teknik kontrol persediaan meminimalkan biaya jumlah pesanan, penyimpanan. Menurut Rianto (2010:78) Economic Order Quantity (EOQ) yaitu total kuantitas barang didapat biaya minimal atau dan sering dikatakan total pembelian optimal.

Definisi sipenulis menyimpulkan Economic Order Quantity (EOQ) yaitu total belian sediaan dilakukan efisien agar biaya sediaan seluruh jadi kecil.

Teknik relatif gampang digunakan dasar asumsi :

1. total mintaan diketahui, konstan, dan independen.

2. Waktu tunggu (lead time) yaitu waktu diantara pesanan, penerima pesan diketahui konstan.

3. Nerima sediaan sifat instan, selesai semuanya. Kata lain, sediaan sebuah pesan datang satu kelompok.

4. Tidak sedia diskon kuantitas.

5. Biaya variabel cuma biaya menyiapkan atau melakukan pesanan (biaya setelan), biaya simpan sediaan kurun waktu tertentu (biaya simpanan).

6. Kehabisan sediaan (kurang sediaan) bisa sepenuh dihindari kalau pesanan dilaksanakan pada waktu yang pas. 


\section{Kerangka Berpikir}

Perusahaan memiliki kebijakan sendiri memenuhi kebutuhan bahan baku. Yankees Bakery dilakukan kebijakan pembeli bahan baku dengan lakukan belian secara terus menerus. Bijakan pembeli bahan baku setiap minggu diterapkan Yankees Bakery untuk dan memperlancar proses produksi, sehingga perusahaan bisa memenuhi pesanan pelanggan tepat waktu. Tapi Yankees Bakery harus perhatikan total sediaan bahan baku yang mau di proses. total bahan baku besar akan dinambah biaya-biaya sediaan, sedangkan total bahan baku terlalu sedikit akan menghambat pemenuhan permintaan konsumen.

Sediaan bahan baku EOQ diawali dengan mengetahui total pembeli bahan baku, pemakai bahan baku dan jumlah sediaan bahan baku. Data dapat dipergunakan menghitung EOQ, sediaan pengaman (safety stock) untuk dan menghindari terjadi kehabisan bahan baku untuk menjamin lancar dalam proses produk, Reorder and Point (ROP) biar pembeli bahan tetap tidak mengganggu proses kelancaran proses produk perusahaan. Setelah menghitung EOQ, safety stock, ROP bisa dilanjutkan melakukan perhitungan biaya jumlah sediaan atau Total Inventory Cost (TIC) untuk ngetahui biaya dikeluarkan perusahaan setiap periode produksi.

Keterangan disini perusahaan mengetahui sediaan bahan baku optimal, dapat dilakukan penghemat biaya jumlah sediaan.

Kerangka berpikir Analisis Metode Economic Order Quantity (EOQ) Sebagai Dasar Pengendali sediaan Bahan Baku (Studi Pada Yankees Bakery, Kecamatan Kertosono) berikut ini : 


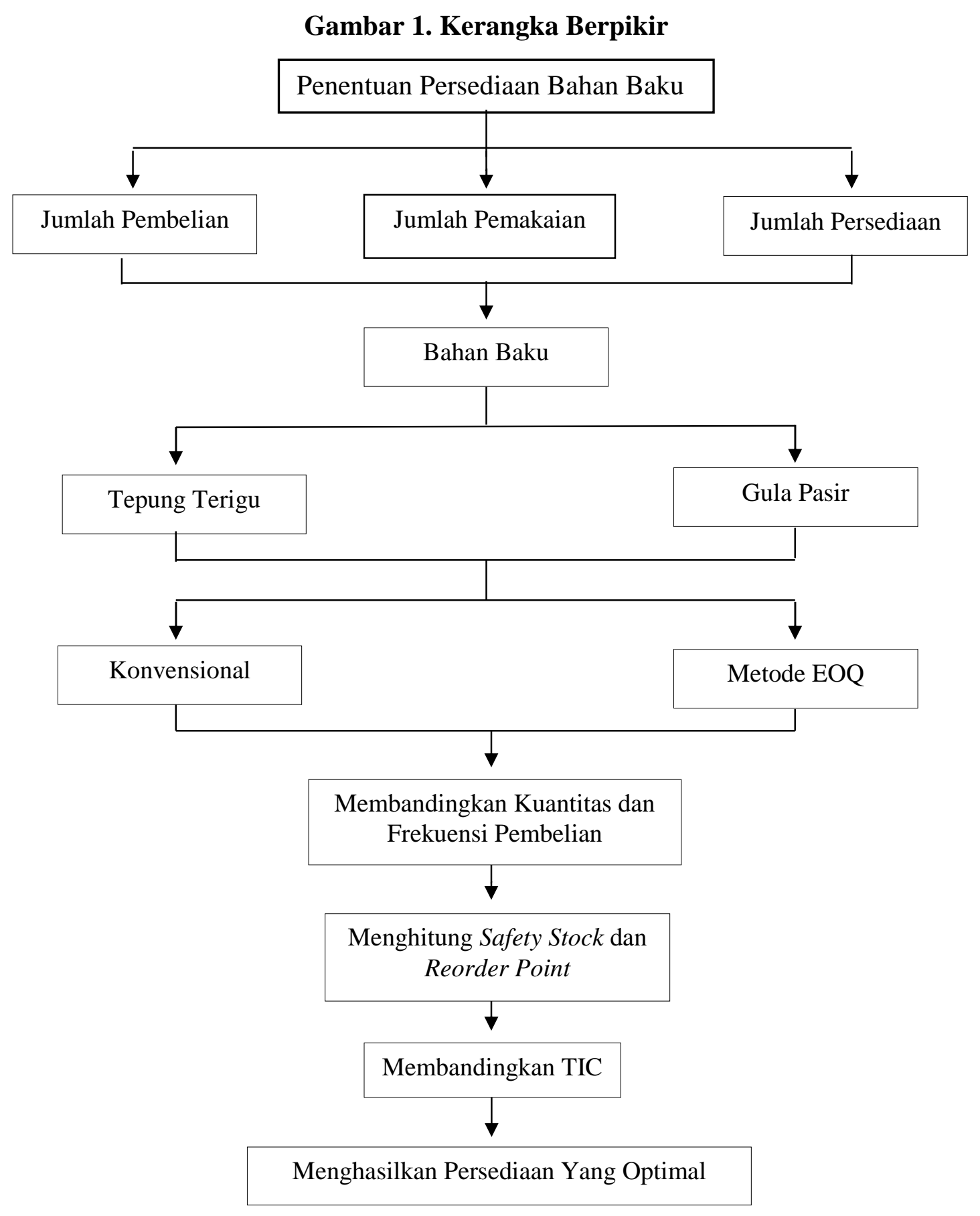

Sumber : Diolah Peneliti (2018) 


\section{METODE PENELITIAN}

\section{Populasi dan Sampel Penelitian}

Meninjau lebih dari wilayah dan populasi, sampel buat jenis peneliti kasus meliputi di daerah sangat sempit (Assauri, 1998:115), maka di dalam peneliti ini tidak ada nama populasi dan sampel tapi langsung di keseluruhan kasus sediaan dan menggunaan bahan dan baku pada Yankees Bakery Kertosono.

\section{Metode Pengumpulan Data}

Mengumpulkan data menurut Arikunto, Suharsimi (2010:275) adalah mengamati variabel yang akan diteliti dengan metode interview, tes observasi, kuesioner, dan sebagainya. Dalam menghimpun data yang dibutuhkan dalam penulisan penelitian ini, maka penulis menggunakan beberapa metode pengumpulan data sebagai berikut :

1. Studi Pustaka

Dalam penelitian ini peneliti mengambil referensi dari buku yang ada di perpustakaan seperti buku tentang persediaan, manajemen operasional dan lain sebagainya.

2. Metode Interview atau wawancara

Wawancara ini melakukan sama pihak terkait dengan topik bahasan, adalah kepada pemilik Yankees Bakery Kertosono.

\section{Dokumentasi}

Dokumen menurut Sugiyono (2007:422) merupakan peristiwa pencatatan data yang sudah. Penelitian metode dokumentasi dipakai dalam hal bentuk data sekunder untuk mengetahui kuantitas pembeli bahan baku, pemakai bahan baku, biaya simpanan dan biaya pesanan di Yankees Bakery.

4. Observasi Data

Menggunakan observasi adalah mengetahui fakta kenyataan yang terjadi di daerah penelitian ini berdasarkan pengamatan/observasi dari sipeneliti. Observasi yang dilaksanakan dengan turun langsung kelapangan melihat kegiatan produksi roti dan kue basah di Yankees Bakery Kertosono. 


\section{Analisis Data}

\section{Analisis Kebutuhan akan Bahan Baku}

diketahui bahwa kebutuhan bahan dan baku pada bulan awal yaitu tahun 2018 memakai metode trend and projection. Mengetahui trend and projection data tentang pengguna bahan dan baku selama tahun 2004 hingga 2006 yaitu:

Tabel 2. Perhitungan Bahan Baku Tepung Usaha Yankees Bakery Triwulan Ketiga dan Triwulan Keempat (Trend Garis Lurus)

\begin{tabular}{|c|c|c|c|c|c|c|c|c|}
\hline \multirow{2}{*}{ No. } & \multirow{2}{*}{\multicolumn{2}{|c|}{ Bulan }} & \multicolumn{2}{|c|}{ Bahan baku (Y) } & \multirow{2}{*}{$\mathbf{X}$} & \multicolumn{2}{|c|}{ XY } & \multirow{2}{*}{$\mathbf{X}^{2}$} \\
\hline & & & $\mathbf{T}$ & $\mathbf{G}$ & & $\mathbf{T}$ & $\mathbf{G}$ & \\
\hline 1. & \multirow{4}{*}{ Juli } & Minggu 1 & 790 & 350 & -23 & -18.170 & -8.050 & 529 \\
\hline 2. & & Minggu 2 & 865 & 350 & -21 & -18.165 & -7.320 & 441 \\
\hline 3. & & Minggu 3 & 890 & 375 & -19 & -16.910 & -7.125 & 361 \\
\hline 4. & & Minggu 4 & 915 & 375 & -17 & -15.555 & -6.375 & 287 \\
\hline 5. & \multirow{4}{*}{ Agustus } & Minggu 1 & 940 & 400 & -15 & -14.100 & -6.000 & 225 \\
\hline 6. & & Minggu 2 & 965 & 425 & -13 & -12.545 & -5.525 & 169 \\
\hline 7. & & Minggu 3 & 965 & 375 & -11 & -10.615 & -4.125 & 121 \\
\hline 8. & & Minggu 4 & 1.015 & 450 & -9 & -9.135 & -4.050 & 81 \\
\hline 9. & \multirow{4}{*}{ September } & Minggu 1 & 1.040 & 400 & -7 & -7.280 & -2.800 & 49 \\
\hline 10. & & Minggu 2 & 1.065 & 425 & -5 & -5.325 & -2.125 & 25 \\
\hline 11. & & Minggu 3 & 1.065 & 400 & -3 & -3.195 & -1.200 & 9 \\
\hline 12. & & Minggu 4 & 1.040 & 400 & -1 & -1.040 & -400 & 1 \\
\hline 13. & \multirow{4}{*}{ Oktober } & Minggu 1 & 890 & 375 & 1 & 890 & 375 & 1 \\
\hline 14. & & Minggu 2 & 940 & 300 & 3 & 2.820 & 900 & 9 \\
\hline 15. & & Minggu 3 & 924 & 325 & 5 & 4.620 & 1.625 & 25 \\
\hline 16. & & Minggu 4 & 924 & 300 & 7 & 6.468 & 2.100 & 49 \\
\hline 17. & \multirow{4}{*}{ November } & Minggu 1 & 924 & 350 & 9 & 8.316 & 3.150 & 81 \\
\hline 18. & & Minggu 2 & 974 & 300 & 11 & 10.714 & 3.300 & 121 \\
\hline 19. & & Minggu 3 & 974 & 325 & 13 & 12.662 & 4.225 & 169 \\
\hline 20. & & Minggu 4 & 974 & 450 & 15 & 14.610 & 6.750 & 225 \\
\hline 21. & \multirow{4}{*}{ Desember } & Minggu 1 & 999 & 450 & 17 & 16.983 & 7.650 & 287 \\
\hline 22. & & Minggu 2 & 999 & 425 & 19 & 18.981 & 8.075 & 361 \\
\hline 23. & & Minggu 3 & 1.024 & 475 & 21 & 21.504 & 9.975 & 441 \\
\hline 24. & & Minggu 4 & 1.074 & 500 & 23 & 24.702 & 11.500 & 529 \\
\hline \multicolumn{3}{|c|}{ Jumlah } & 23.175 & 1.550 & 0 & 11.235 & 4.530 & 4.596 \\
\hline \multicolumn{3}{|c|}{ Rata - Rata Per Minggu } & 965,625 & 387,5 & & & & \\
\hline
\end{tabular}




\section{Perhitungan EOQ}

Jumlah yang dipakai bahan dan baku tepung dan gula, per unit, besar biaya di pesanan setiap beberapa kali pesan dan biaya simpanan Yankees Bakery yaitu triwulan ketiga dan triwulan keempat di tahun 2017

Tabel 3. Pemakaian bahan baku, harga per unit, total biaya penyimpanan dan biaya pemesanan (tepung dan gula) pada triwulan ketiga dan keempat tahun 2017

\begin{tabular}{|l|r|r|r|r|}
\hline \multirow{2}{*}{ Uraian } & \multicolumn{2}{c|}{ Triwulan Ketiga } & \multicolumn{1}{c|}{ Triwulan Keempat } \\
\cline { 2 - 5 } & \multicolumn{1}{c|}{ Tepung } & \multicolumn{1}{c|}{ Gula } & \multicolumn{1}{c|}{ Tepung } & \multicolumn{1}{c|}{ Gula } \\
\hline Jumlah & 11.555 & 4.725 & 11.620 & 4.575 \\
\hline Harga/kg & 7.000 & 12.000 & 7.000 & 12.000 \\
\hline Total Biaya & 80.885 .000 & 56.700 .000 & 81.340 .000 & 54.900 .000 \\
\hline Biaya Pemesanan & 700.000 & 100.000 & 820.000 & 110.000 \\
\hline $\begin{array}{l}\text { Biaya Penyimpanan } \\
\text { (Rp/unit) }\end{array}$ & 700 & 1.200 & 700 & 1.200 \\
\hline
\end{tabular}

\section{Penentuan Safety Stock}

Hitungan safety and stock melakukan buat melindungi perusahaan dari resiko keterlambatan bahan dan baku menghindari adanya kehabisan penerima bahan dan baku yang telah dipesan. Untuk melihat besarnya safety and stock dipergunakan analisis statistic yaitu menghitungkan simpangan yang akan terjadi antara perkiraan pemakai dan pemakaian yang sebenarnya

Pada batas toleransi yang akan digunakan yaitu nilai 5\% di atas rata-rata dan 5\% di bawah perkiraan. Dengan menggunakan dua batas toleransi tersebut maka nilai yang standar deviasi digunakan yaitu 1,65. Perhitungan safety and stock pada Yankees Bakery bisa dilihat di tabel sebagai berikut :

Tabel 4. Standar Deviasi triwulan ketiga tahun 2017

\begin{tabular}{|c|c|c|c|c|c|c|}
\hline \multirow{2}{*}{ No } & \multirow{2}{*}{\multicolumn{2}{|c|}{ Bulan }} & Penggunaan & Perkiraan & Deviasi & Kuadrat \\
\hline & & & $\mathrm{X}$ & $\mathrm{Y}$ & $(\mathrm{X}-\mathrm{Y})$ & $(\mathrm{X}-\mathrm{Y})^{2}$ \\
\hline 1. & \multirow{4}{*}{ Juli } & Minggu 1 & 790 & \multirow{8}{*}{963} & -173 & 29.929 \\
\hline 2. & & Minggu 2 & 865 & & -98 & 9.604 \\
\hline 3. & & Minggu 3 & 890 & & -73 & 5.329 \\
\hline 4. & & Minggu 4 & 915 & & -48 & 2.304 \\
\hline 5. & \multirow{4}{*}{ Agustus } & Minggu 1 & 940 & & -23 & 529 \\
\hline 6. & & Minggu 2 & 965 & & 2 & 4 \\
\hline 7. & & Minggu 3 & 965 & & 2 & 4 \\
\hline 8. & & Minggu 4 & 1.015 & & 52 & 2.704 \\
\hline
\end{tabular}




\begin{tabular}{|c|c|c|c|c|c|}
\hline & \multirow{4}{*}{ September } & Minggu 1 & 1.040 & 77 & 5.929 \\
\hline \multirow{3}{*}{$\begin{array}{l}9 . \\
10 . \\
11 . \\
12\end{array}$} & & Minggu 2 & 1.065 & 102 & 10.404 \\
\hline & & Minggu 3 & 1.065 & 102 & 10.404 \\
\hline & & Minggu 4 & 1.040 & 77 & 5.929 \\
\hline & Jumla & & 11.555 & & 83.073 \\
\hline
\end{tabular}

Tabel 5. Standar Deviasi triwulan ketiga tahun 2017

\begin{tabular}{|c|c|c|c|c|c|c|}
\hline \multirow{2}{*}{ No } & \multirow{2}{*}{\multicolumn{2}{|c|}{ Bulan }} & Penggunaan & Perkiraan & Deviasi & Kuadrat \\
\hline & & & $\mathrm{X}$ & $\mathrm{Y}$ & $(\mathrm{X}-\mathrm{Y})$ & $(X-Y)^{2}$ \\
\hline 1. & \multirow{4}{*}{ Juli } & Minggu 1 & 350 & \multirow{12}{*}{394} & -44 & 1.936 \\
\hline 2. & & Minggu 2 & 350 & & -44 & 1.936 \\
\hline 3. & & Minggu 3 & 375 & & -19 & 361 \\
\hline 4. & & Minggu 4 & 375 & & -19 & 361 \\
\hline 5 & \multirow{4}{*}{ Agustus } & Minggu 1 & 400 & & 6 & 36 \\
\hline 6 & & Minggu 2 & 425 & & 31 & 961 \\
\hline 7. & & Minggu 3 & 375 & & -19 & 361 \\
\hline 8. & & Minggu 4 & 450 & & 56 & 3.136 \\
\hline 9. & \multirow{4}{*}{ September } & Minggu 1 & 400 & & 6 & 36 \\
\hline 10. & & Minggu 2 & 425 & & 31 & 961 \\
\hline 11. & & Minggu 3 & 400 & & 6 & 36 \\
\hline 12. & & Minggu 4 & 400 & & 6 & 36 \\
\hline \multicolumn{3}{|c|}{ Jumlah } & 4.725 & & & 10.157 \\
\hline
\end{tabular}

Tabel 6. Standar Deviasi triwulan keempat tahun 2017

\begin{tabular}{|c|c|c|c|c|c|c|}
\hline \multirow{2}{*}{ No } & \multirow{2}{*}{\multicolumn{2}{|c|}{ Bulan }} & Penggunaan & Perkiraan & Deviasi & Kuadrat \\
\hline & & & $X$ & $\mathrm{Y}$ & $(\mathrm{X}-\mathrm{Y})$ & $(X-Y)^{2}$ \\
\hline 1. & \multirow{4}{*}{ Oktober } & Minggu 1 & 890 & \multirow{12}{*}{968} & -78 & 6.084 \\
\hline 2. & & Minggu 2 & 940 & & -28 & 784 \\
\hline 3. & & Minggu 3 & 924 & & -44 & 1.936 \\
\hline 4. & & Minggu 4 & 924 & & -44 & 1.936 \\
\hline 5. & \multirow{4}{*}{ November } & Minggu 1 & 924 & & -44 & 1.936 \\
\hline 6. & & Minggu 2 & 974 & & 6 & 36 \\
\hline 7. & & Minggu 3 & 974 & & 6 & 36 \\
\hline 8. & & Minggu 4 & 974 & & 6 & 36 \\
\hline 9. & \multirow{4}{*}{ Desember } & Minggu 1 & 999 & & 31 & 961 \\
\hline 10. & & Minggu 2 & 999 & & 31 & 961 \\
\hline 11. & & Minggu 3 & 1.024 & & 56 & 3.136 \\
\hline 12. & & Minggu 4 & 1.074 & & 56 & 3.136 \\
\hline \multicolumn{3}{|c|}{ Jumlah } & 11.620 & & & 20.978 \\
\hline
\end{tabular}


Tabel 7. Standar Deviasi triwulan keempat tahun 2017

\begin{tabular}{|c|c|c|c|c|c|c|}
\hline \multirow{2}{*}{ No. } & \multirow{2}{*}{\multicolumn{2}{|c|}{ Bulan }} & Penggunaan & Perkiraan & Deviasi & Kuadrat \\
\hline & & & $\mathrm{X}$ & $\mathrm{Y}$ & $(\mathrm{X}-\mathrm{Y})$ & $(X-Y)^{2}$ \\
\hline 1. & \multirow{4}{*}{ Oktober } & Minggu 1 & 375 & \multirow{12}{*}{381,25} & $-6,25$ & 39,06 \\
\hline 2. & & Minggu 2 & 300 & & $-81,25$ & $6.601,56$ \\
\hline 3. & & Minggu 3 & 325 & & $-56,25$ & $3.164,06$ \\
\hline 4. & & Minggu 4 & 300 & & $-81,25$ & $6.601,56$ \\
\hline 5. & \multirow{4}{*}{ November } & Minggu 1 & 350 & & $-31,25$ & 976,56 \\
\hline 6. & & Minggu 2 & 300 & & $-81,25$ & $6.601,56$ \\
\hline 7. & & Minggu 3 & 325 & & $-56,25$ & $3.164,06$ \\
\hline 8. & & Minggu 4 & 450 & & 68,75 & $4.726,56$ \\
\hline 9. & \multirow{4}{*}{ Desember } & Minggu 1 & 450 & & 68,75 & $4.726,56$ \\
\hline 10. & & Minggu 2 & 425 & & 43,75 & $1.914,06$ \\
\hline 11. & & Minggu 3 & 475 & & 93,75 & $8.789,06$ \\
\hline 12. & & Minggu 4 & 500 & & 118,75 & $14.101,56$ \\
\hline \multicolumn{3}{|c|}{ Jumlah } & 4.575 & & & $61.406,22$ \\
\hline
\end{tabular}

\section{PEMBAHASAN}

Data yang akan didapat Yankees Bakery melihatkan akan hubungan diantara EOQ, Safety and Stock, ROP dan Maximum and Inventory bahan dan baku tepung, gula pada triwulan ketiga dan triwulan keempat tahun 2017 adalah sebagai berikut :

Tabel 8. Total Biaya Persediaan Bahan Baku Menurut EOQ dan Total Biaya Persediaan Bahan Baku Yang Dijalankan Yankees Bakery serta Penghematan yang Diperoleh Pada Triwulan Ketiga - Triwulan Keempat Tahun 2017

\begin{tabular}{|c|l|l|l|l|}
\hline & \multicolumn{2}{|c|}{ Triwulan Ketiga } & \multicolumn{2}{c|}{ Triwulan Keempat } \\
\cline { 2 - 5 } & \multicolumn{1}{|c|}{ Tepung } & \multicolumn{1}{c|}{ Gula } & \multicolumn{1}{c|}{ Tepung } & Gula \\
\hline $\begin{array}{c}\text { TIC menurut } \\
\text { Yankees Bakery }\end{array}$ & Rp. 1.374 .100 & Rp. 572.500 & Rp. 1.497 .831 & Rp. 567.500 \\
\hline TIC menurut EOQ & Rp. 971.420 & Rp. 307.408 & Rp. 1.054.346 & Rp. 317.254 \\
\hline Penghematan & Rp. 402.680 & Rp. 265.092 & Rp. 443.485 & Rp. 250.246 \\
\hline
\end{tabular}

Bisa mengetahui perbandingan jumlah biaya sediaan bahan dan baku menurut EOQ dengan jumlah sediaan bahan dan baku telah dijlankan Yankees Bakery dengan penghematan menghasilkan di triwulan ketiga - triwulan keempat tahun 2017 


\section{KESIMPULAN DAN SARAN}

\section{Kesimpulan}

Berdasarkan dari hasil peneliti, pembahasan, bisa disimpulkan bahwa pengendali sediaan bahan baku berdasarkan metode EOQ bisa lebih optimal dan atau ekonomis dibandingkan metode konvensional pada diterapkan Yankees Bakery. Sehingga didapat metode hitungan yang sangat lebih efektif dan atau efisien menentukan sediaan optimal. dibuktikan dengan adanya selisih hitungan Total Inventory Cost (TIC) diantara metode konvensional Yankees Bakery dengan menggunakan metode Economic and Order Quantity (EOQ).

Hal yang dapat dibuktikan yaitu dari triwulan ketiga tahun 2017 jumlah biaya jumlah sediaaan sehingga gunakan konvensional atau untuk bahan baku tepung terigu senilai Rp. 1.374.100 bahan baku gula pasir senilai Rp.572.500, sedangkan biaya total persediaan EOQ juga bisa digunakan bahan dan baku tepung terigu senilai Rp. 971.420 bahan dan baku gula pasir senilai Rp. 307.408, hasil tersebut digunakan EOQ Yankees Bakery juga bisa mengirit biaya bahan dan baku tepung terigu senilai Rp. 402.680 juga untuk bahan dan baku gula pasir senilai yaitu Rp. 265.092.

Sedangkan pada triwulan keempat tahun 2017 samapai jumlah biaya total persediaan dengan menggunakan metode konvensional dan atau bahan dan baku tepung terigu senilai Rp. 1.497.831 atau bahan dan baku gula pasir senilai Rp. 567.500, sedangkan biaya total persediaan digunakan metode EOQ dan bahan dan baku tepung terigu sebesar Rp. 1.054.346 untuk bahan dan baku gula pasir sebesar nilai yaitu Rp.317.254, hasil diperoleh maka EOQ Yankees Bakery bisa menghemat biaya bahan dan baku tepung terigu sebesar nilai yaitu Rp. 443.485 dan atau bahan dan baku gula pasir sebesar nilai yaitu Rp. 250.246.

\section{Saran}

Berdasarkan kesimpulan dan hasil peneliti tersebut, maka penelitian menyarankan sebagai berikut :

1. Buat Yankees Bakery untuk dan memperoleh keuntungan yang lebih besar alangkah baiknya menggunakan metode EOQ dalam menentukan persediaan bahan baku, karena dengan menggunakan metode yang efektif dan atau efisien ini perusahaan akan lebih mudah menjalankan perusahaan dengan optimal. 
2. Buat penelitian yang lain dan yang akan melakukan penelitian sejenis dengan menggunakan subjek persediaan optimal pada usaha kecil, mikro dan atau menengah mengharapkan untuk dibandingkan dengan metode lain mengenai sediaan optimal, sehingga didapat hasil yang lebih efektif dan atau efisien.

\section{DAFTAR PUSTAKA}

Afif, rahmadi nur. (2015). analisis kualitas pelayanan, kualitas produk dan kenyamanan terhadap keputusan konsumen dalam menggunakan jasa sport center (studi kasus mensana sport center futsal kediri). KOMPILEK, 7(1), 37-45.

Dewandaru bothy, purnamaningsih nining. (2016). Strategi dalam memajukan industri kreatif dan pengembangan ekonomi lokal sebagai daya tarik wisata (study pada kesenian jaranan dikota kediri). EKONIKA, 1(2), 170-187. https://doi.org/http://dx.doi.org/10.30737/ekonika.v1i2.4

Arikunto, Suharsimi. 2006. Prosedur Penelitian Suatu Pendekatan Praktik. Jakarta: Rineka Cipta.

Arikunto, S. 2010. Prosedur Penelitian : Suatu Pendekatan Praktik . (Edisi Revisi). Jakarta : Rineka Cipta.

Assauri, Sofyan. 1998. Manajemen Produksi dan Operasi, Edisi Revisi. Jakarta: BPFE UI.

Atika Sari, Ningrum. 2016. Analisis Pengendalian Persediaan Bahan Baku Dengan EOQ Pada Perusahaan Kecap Cap Mencco Kediri. Artikel Skripsi. Kediri : Fakultas Ekonomi Prodi Akuntansi Universitas Nusantara Persatuan Guru Republik Indonesia.

Azwar, Saifuddin. 2012. Metode Penelitian. Yogyakarta: Pustaka Pelajar

Deitiana, Tita. 2011. Manajemen Operasional Strategi dan Analisa Service dan manufaktur. Jakarta: Mitra Wacana Media.

Gede Agus Darmawan, Wayan Cipta, Ni Nyoman Yulianthini.2015. Penerapan Economic Order Quantity (EOQ) Dalam Pengelolaan Persediaan Bahan Baku Tepung Pada Usaha Pia Ariawan Di Desa Banyuning Tahun 2013. e-Journal Bisma Universitas Pendidikan Ganesha Jurusan Manajemen Volume 3.

Haming, Murdifin dan Nurnajamuddin. 2007. Manajemen Produksi Modern. Jakarta: PT Bumi Aksara.

Hanarista Fajrin, Elwidho.2015. Analisis Pengendalian Persediaan Bahan Baku Dengan Metode Economic Order Quantity (EOQ) Pada Perusahaan Roti Bonansa. Skripsi. Semarang : Jurusan Manajemen Fakultas Ekonomi Universitas Negeri Semarang.

Heizer, Jay dan Barry, Render. 2010. Operations Management: Manajemen Operasi. Buku 2. Edisi Kesembilan. Jakarta: Salemba Empat.

Hermawan, Asep. 2009. Penelitian Bisnis Paradigma Kuantitatif. Jakarta: Grasindo.

Kuncoro, Mudrajad. 2011. "Metode Kuantitatif". Edisi Keempat, YogyakartaUPP-STIM YKPN.

Kusuma, Hendra. 2009. Manajemen Industri, Diktat Kuliah, Jurusan Teknik Mesin UNSRAT, Manado. 
Nafarin, M. 2004. Penganggaran Perusahaan. Edisi Revisi. Jakarta: Salemba Empat.

Nugraha, Aditya.2015.Analisis Pengendalian Bahan Baku Menggunakan Metode Economic Order Quantity (EOQ). Skripsi. Semarang : Jurusan Manajemen Fakultas Ekonomi Universitas Negeri Semarang.

Putra, Yudiarto Perdana (2015) Analisis Laporan Keuangan Berdasarkan Rasio Likuiditas, Solvabilitas, dan Rentabilitas untuk menilai kinerja keuangan pada koperasi Manunggal Universitas Kadiri. Kompilek Vol. 7 No. 1 Tahun 2015

Rahardyan, Prihasdi. 2012. Efisiensi Metode Economic Order Quantity (EOQ) Dalam Pengambilan Keputusan Pembelian Bahan Baku Dan Pengaruhnya Terhadap Total Biaya Pembelian Pada PT Amitex (Amanah Mitra Industri) Buaran Kabupaten Pekalongan. Skripsi. Semarang: Fakultas Ekonomika dan Bisnis Universitas Diponegoro.

Rangkuti, Manajemen Persediaan. Jakarta: Raja Grafindo Persada.Freddy. 2004.

Reny Warisman, Nengah Sudjana, M.G. Wi Endang NP. 2011, "Penggunaan Teknik EOQ (Economic Order Quantity) \& ROP (Repeat Order) Dalam Upaya Pengendalian Efisiensi Persediaan (Studi Pada Cv. Subur Abadi Tulungagung)".

Rianto, Bambang. 2010. "Dasar-dasar Pembelanjaan Perusahaan”. BPFEYogyakarta.

Rifqi, Lathif Hanafir. 2012. Efisiensi Biaya Pengendalian Bahan baku Menggunakan Metode Economic Order Quantity (EOQ) pada PT. Sari Warna Asli V Kudus. Skripsi. Semarang: Fakultas Ekonomi UNNES.

Sakkung, Carien Valerie dan Sinuraya Candra. 2011. Perbandingan Metode Eoq (Economic Order Quantity) Dan Jit (Just In Time) Terhadap Efisiensi Biaya Persediaan dan Kinerja Non-Keuangan (Studi Kasus Pada PT. Indoto Tirta Mulia. Dalam jurnal Ilmiah Akuntansi Nomor 05. Hal 1-19. Universitas Kristen Maranatha.

Simbar, Mutiara. 2014. Analisis Pengendalian Persediaan Bahan Baku Kayu Cempaka Pada Industri Mebel Dengan Menggunakan Metode EOQ (Studi Kasus Pada UD. Batu Zaman) (Jurnal Ilmiah). Universitas Sam Ratulangi, Manado.

Slamet, Achmad. 2007. Penganggaran Perencanaan dan Pengendalian Usaha. Semarang: UNNES PRESS.

Sudjana. 2005. Metoda Statistika. Bandung : Tarsito.

Sugiyono. 2007. Statistika untuk Penelitian. Bandung: Alfabeta.

Sutarti, Sutriyono, Dhayal Gustopo.2016. Analisis Pengendalian Persediaan Bahan Baku Menggunakan Metode Economic Order Quantity Dalam Upaya Meningkatkan Efiiensi (Studi Kasus Pada PT. Pancaran Mulia Sejati).Jurnal Teknologi dan Manajemen Industri, Vol. 2 No.2, Agustus 2016. Malang : Pascasarjana Institut Teknologi Nasional Malang.

Sumayang, Lalu. 2003. Dasar-dasar Manajemen Produksi dan Operasi. Jakarta: Salemba Empat.

Wardani, Iqra. Analisis Pengendalian Persediaan Bahan Baku Dalam Upaya Menekan Biaya Produksi Pada PT. Eastern Parl Flour Mills Di Makassar. Skripsi. Makassar : Fakultas Ekonomi dan Bisnis Jurusan Manajemen Universitas Hasanuddin. 